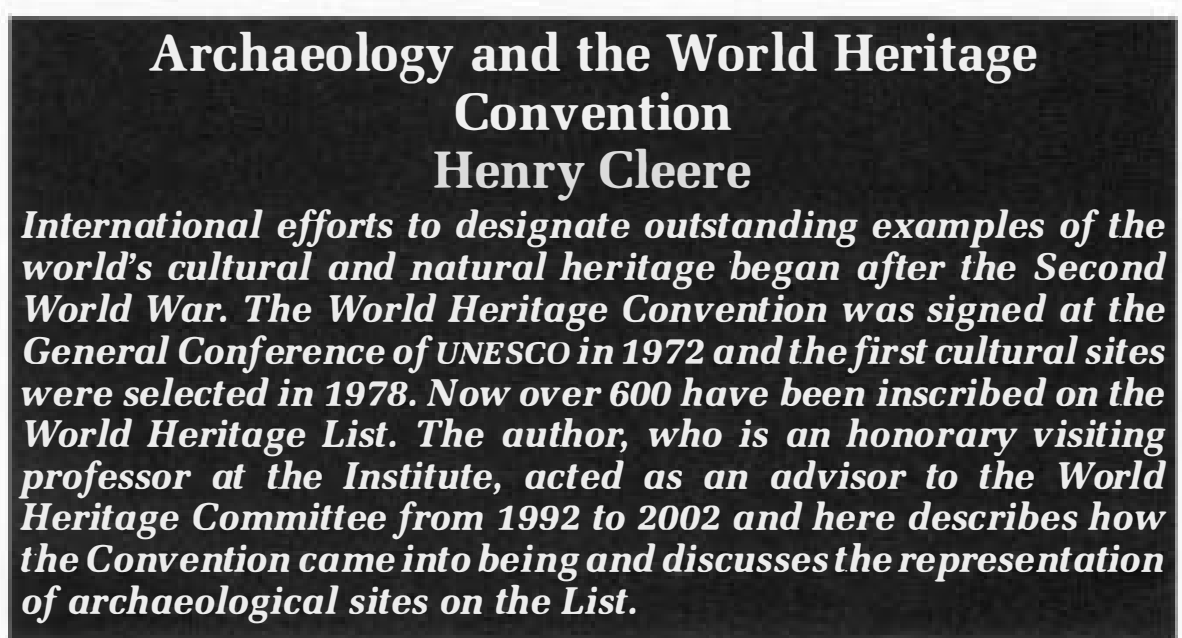

D

uring the 1960 s, rapid worldwide economic development coincided with widespread improvements in agriculture and the treatment of disease. These changes were heralded as improving the standard of living of many of the less prosperous inhabitants of the world, but less heed was paid to the adverse impact that they were having on the cultural and natural heritage of the planet. It was not recognized until the middle of the decade that, without some form of control, much of this heritage would disappear for ever, such was the magnitude of the threats. Environmental protection groups in Europe and North America began to alert governments to the growing seriousness of the situation and to demand urgent action at national and international level.

\section{The World Heritage Convention}

From the early 1920s there had been discussions within the League of Nations about the creation of an international fund to assist those countries with rich remains from the past but with limited financial and human resources, notably those in Asia and Latin A merica. By the outbreak of the Second World War no agreement had been reached, but, with the creation of the United Nations Educational, Scientific and Cultural Organization (UNESCO) in 1946 these discussions began again. One of the first results was an international campaign to record and rescue archaeological sites that would be flooded by the construction of the Aswan High Dam on the Nile in Upper Egypt. In 1964 the International Union of Architects produced the Venice Charter, which outlined the basic principles of architectural and archaeological conservation, and in 1965 this was followed by the creation at a meeting in Warsaw of the International Council on Monuments and Sites (ICOMOS). ${ }^{1}$

In 1965 impetus was also given to the protection of the natural heritage by the USA following a conference at the White House on international cooperation, supported by the International Union for the Conservation of Nature (now the IUCN -
World Conservation Union). The two initiatives were brought together, and in November 1972 at the General Conference of UNESCO held in Paris the Convention concerning the protection of the world cultural and natural heritage, better known as the World Heritage Convention, was signed, after long and often tortuous debates. A World Heritage Committee was formed, ${ }^{2}$ with responsibility for selecting outstanding sites and monuments and inscribing them on a World Heritage List. The first inscriptions were made at a meeting of the World Heritage Committee in 1978 , since when the number of World Heritage cultural sites and monuments has risen to 605 , in 128 of the 177 countries that have ratified the Convention (known as States Parties to the Convention). ${ }^{3}$

In its preamble the Convention recognizes that "parts of the ... heritage are of outstanding interest and therefore need to be preserved as part of the world heritage of mankind as a whole" and calls upon "the international community as a whole to participate in the protection of the . . heritage of outstanding value". Article 1 defines the "cultural heritage" under three categories:

Monuments: architectural works, works of monumental sculpture and painting, elements and structures of an archaeological nature, inscriptions, cave dwellings and combinations of features, of outstanding universal value from the point of view of history, art or science

Groups of buildings: groups of separate or connected buildings which, because of their architecture, their homogeneity or their place in the landscape, are of outstanding universal value from the point of view of history, art or science

Sites: works of man or the combined works of nature and of man, and areas including archaeological sites which are of outstanding universal value from the historical, aesthetic, ethnological or anthropological points of view.

The fundamental criterion common to these definitions is that of "outstanding universal value", a criterion that is impres- sive but vague. It has therefore been interpreted in more precise terms. Six criteria were identified for cultural properties and fourfornatural properties. The six cultural criteria $^{4}$ require that nominated sites and monuments should: "(i) represent a masterpiece of human creative genius; (ii) exhibit an important interchange of human values, over a span of time or within a cultural area of the world, on developments in architecture, monumental arts or town-planning and landscape design; (iii) bear a unique or at least exceptional testimony to a civilization or cultural tradition which is living or which has disappeared; (iv) be an outstanding example of a type of building or architectural ensemble or landscape which illustrates (a) significant stage(s) in human history; (v) be an outstanding example of a traditional human settlement or land-use which is representative of a culture (or cultures), especially when it had become vulnerable under the impact of irreversible change; (vi) be directly or tangibly associated with events or living traditions, with ideas, or with beliefs, with artistic and literary works of outstanding universal significance."

To qualify for listing a s World Heritage Site, a property must conform with one or more of these criteria. It must also meet the Committee's stringent requirements regarding the management and conservation of the property and of its authenticity.

\section{The World Heritage List}

The World Heritage Committee has long been concerned about the representative nature of the World Heritage List. In 1992 three categories of cultural heritage were identified as being under-represented on the List: the architectural heritage of the twentieth century, industrial heritage, and cultural landscapes. ${ }^{5}$ This was attributed, in the case of the first two, to an overrestrictive interpretation of the intentions of the Convention and the definitions in Article 1, quoted above, and in the case of cultural landscapes to difficulties in defining them. There was also a glaring geographical imbalance, a disproportionate number of cultural sites and monuments being located in Europe.

However, despite substantial intellectual effort being put into trying to rectify this situation, the imbalance in the representative nature of the List persists. A systematic analysis of the List in 2002 by ICOMOS revealed that more than half the properties on it were from the EuropeNorth America region (which includes Israel and Turkey) compared with 18 per cent from the Asia-Pacific region, 12 per cent from the Latin America-Caribbean region, 5 per cent from the Arab States, and only 5 per cent from sub-Saharan Africa. A similar gross imbalance is reflected in the analysis of the List by category. More than 40 per cent of the World Heritage Sites and monuments are historic buildings and 


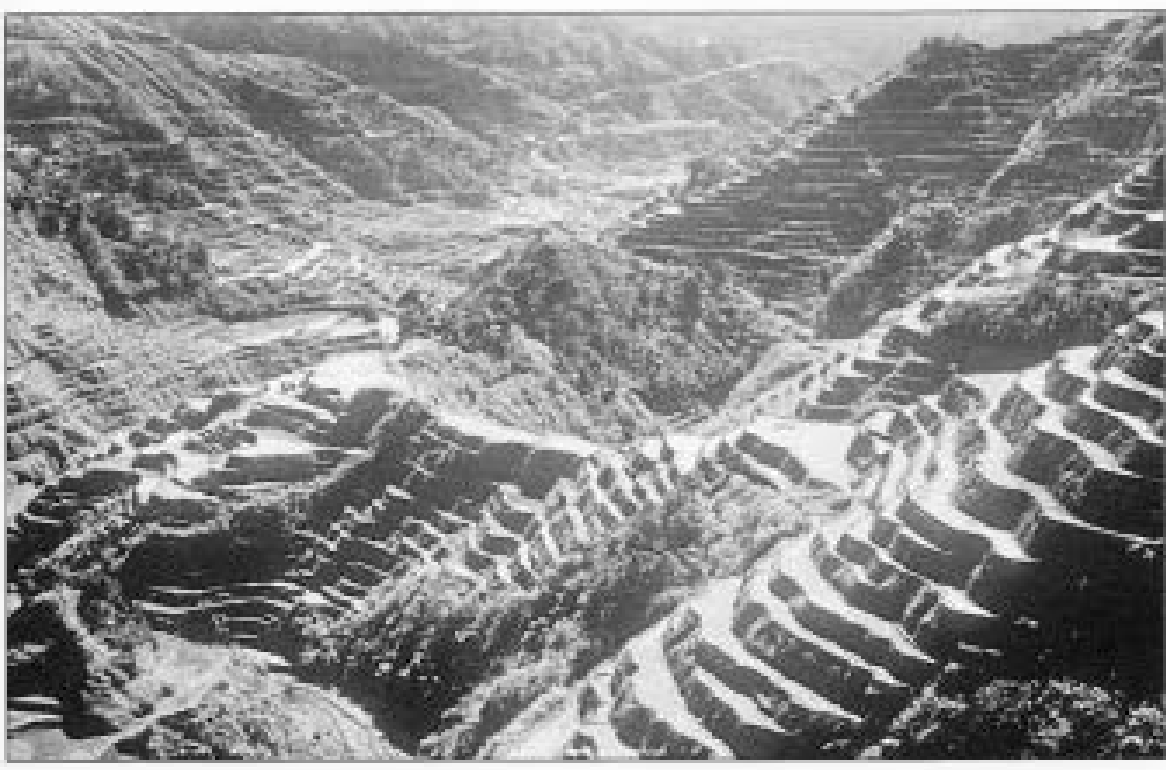

Figure 1 Wet-padi (rice) terraces of the Ifugao at Baraue, Luzon, Philippines.

ensembles of various kinds, 18 per cent are historic towns, and 12 per cent archaeological sites, whereas only 7 per cent are cultural landscapes, 5 per cent are industrial properties, and 1 per cent are heritage of the late nineteenth and twentieth centuries.

In its conclusions ICOMOS drew attention to certain lacunae that need to be filled if the broad interpretation of cultural heritage implicit in Article 1 of the Convention is to be fully realized. It laid particular stress on those non-monumental cultures which nonetheless represent significant manifestations of human achievement. These include the few surviving nomadic
Transhumance (the seasonal movement of herders with their livestock) is still widely practised around the world, but the only landscape of this kind currently on the List is the Pyrenean trans-frontier region of Mont Perdu, between France and Spain. Irrigation is an essential component of agriculture in many regions of the world, but the only example on the List is the remarkable fourth-century BC system at Dujangyan in China, which continues to maintain the fertility of the Chengdu valley in Sichuan.

Other notable lacunae on the List are examples of the great diversity of vernacular architecture, and the monuments of non-Christian religions such as Islam, Buddhism, Hinduism and Judaism, as well as the cult sites of animistic religions and other systems of belief such as shamanism.

\section{Archaeological sites on the List}

The archaeological sites and monuments on the World Heritage List contain few surprises. The important fossil-hominid sites are mostly there: Zhoukoudian (the Peking Man site), Sangiran (famous for Java Man), a group of sites in South Africa around Sterkfontein, and several of the important East African rift-valley sites in Ethiopia, Kenya and Tanzania.

The ancient riverine civilizations are represented by most of the best known sites in Egypt, but the Indus valley civilization is represented only by Mohenjodaro (Fig. 2), and ancient Mesopotamia only by Ashur and Hatra. The early archaeological sites of sub-Saharan Africa, apart from those with exceptional rock art or related to fossil hominids, have so far been ignored, with the exception of the

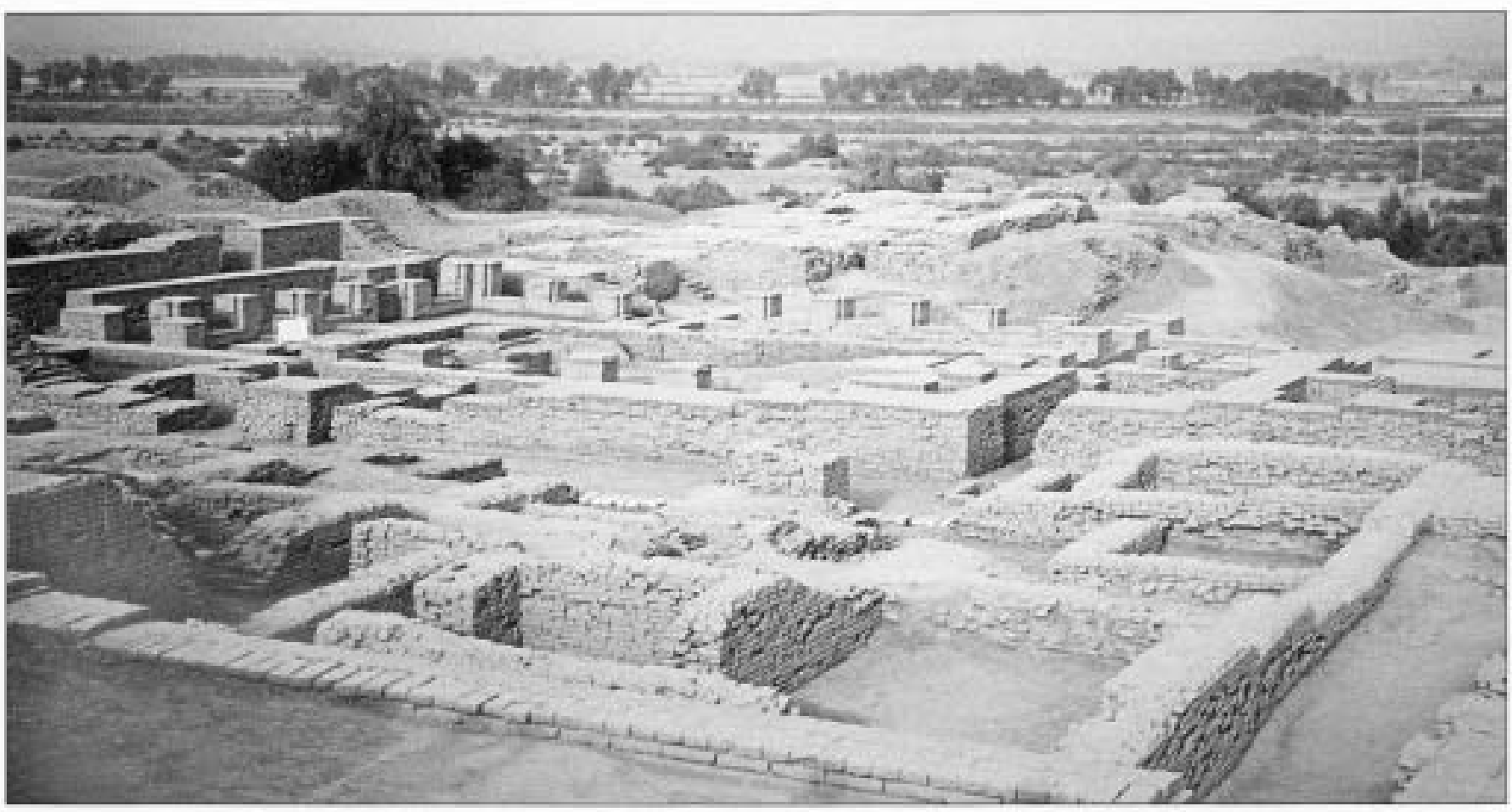

Figure 2 General view of Mohenjo-daro, a site of the Indus Valley civilization, Pakistan. 


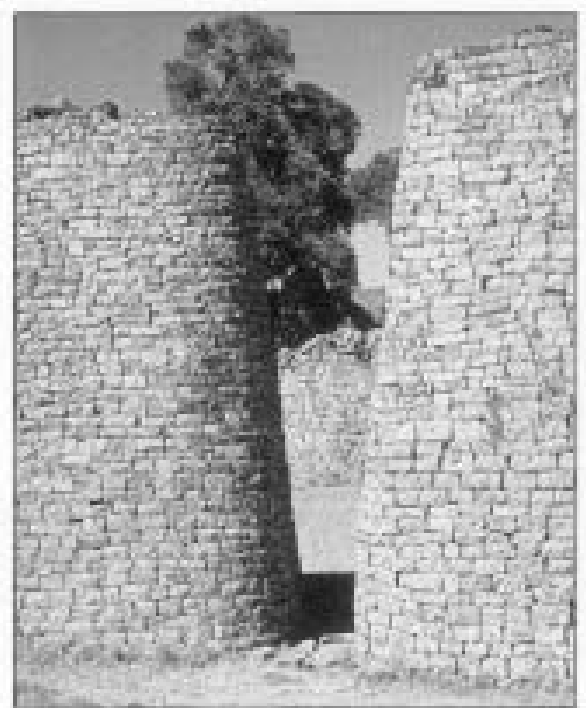

Figure 3 The nort heast entrance to the elliptical building at Great Zimbabwe, Zimbabwe.

ruins of Great Zimbabwe (Zimbabwe, Fig. 3) and the slightly earlier settlement of Mapungubwe (South Africa), which has a particularly dramatic location.

The classical Mediterranean civilizations are, by contrast, well represented. Turkey has the Hittite site of Hattusha, Nemrut Dag and Troy. There are many classical sites across North Africa: Leptis Magna in Libya, Carthage and Dougga in Tunisia (Fig. 4), Tipasa in Algeria and, in Morocco, Timgad and Volubilis (where a team from the Institute of Archaeology is working). ${ }^{6}$ In southern Europe there is a similar wide range of famous sites, from Mérida and Tarragona in Spain, through Arles and Nîmes in France, Agrigento, Aquileia, Pompeii, and the Piazza Armerina villa in Italy, Diocletian's Palace in Croatia, Butrint in Albania, and most of the great Greek sites such as the A thens Acropolis, Delos (Fig. 5), Delphi, Epidauros,

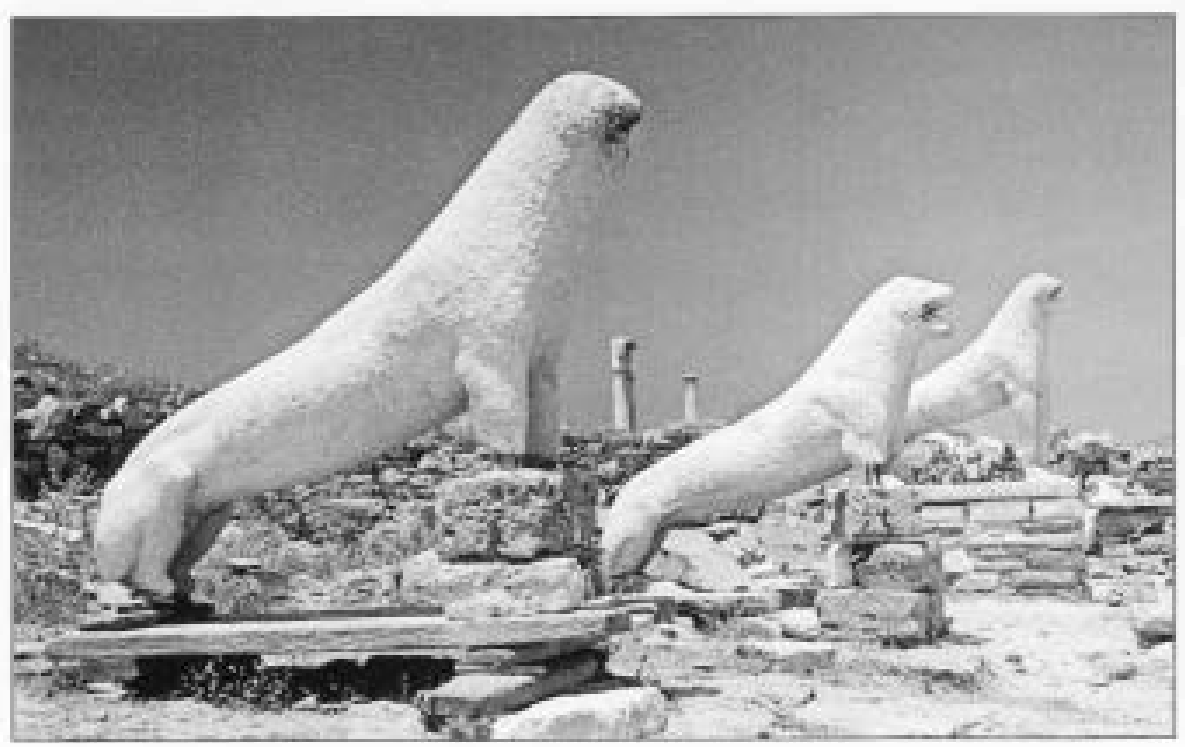

Figure 5 The Portico of the Lions, Delos, Greece.
Knossos, Mycenae and Olympia. In Britain Hadrian's Wall is on the List, and there is currently a project to add the entire Roman Limes (which demarcated the imperial frontier) from Scotland south and east to the Black Sea.

European prehistory is represented more sparsely. Stonehenge and Avebury are listed, together with the Neolithic flint mines at Spiennes (Belgium, Fig. 6), the

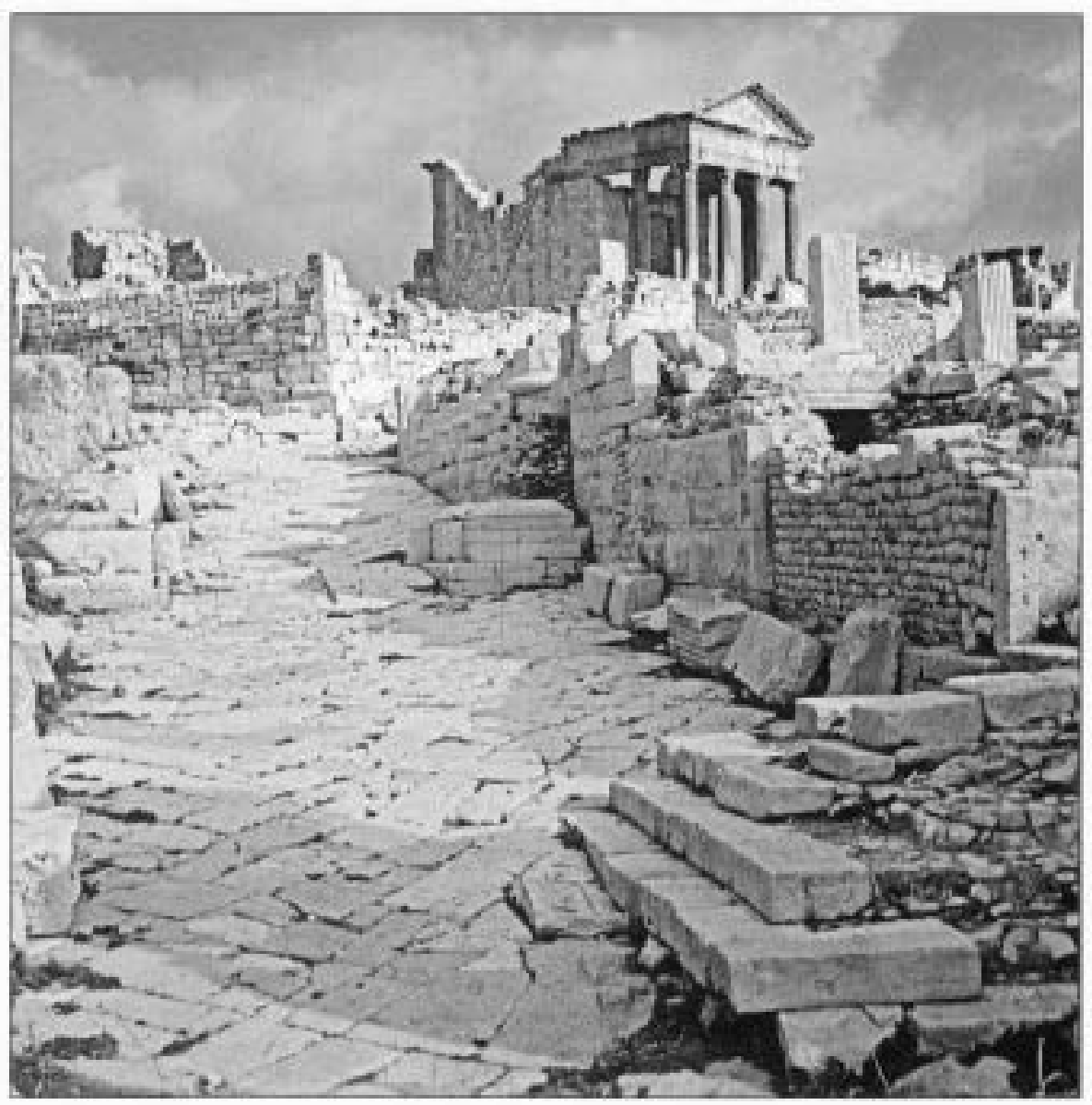

Figure 4 Part of the Roman town of Dougga, Tunisia.

Bronze Age cairn cemetery of Samallahdenmäki (Finland), the Newgrange group of chambered tombs in the Boyne valley (Ireland), and the Iron Age sites at Hallstatt in Austria. To this rather patchy picture of the prehistory of northern Europe can be added prehistoric sites farther south, such as the Thracian tombs of Kazanlak and Sveshtari (Bulgaria), Neolithic Choirokhoitia (Cyprus), the nuraghe (conical towers) of Barumini in Sardinia, the great megalithic temples of Malta, and the Palaeolithic site of Atapuerca (Spain).

Rock art in Europe is well represented on the List. Such sites include Altamira (Spain), the Côa valley engravings (Portugal), Lascaux and the other painted caves of the Vézère valley (France), Valcamonica (Italy), Alta (Norway) and Tanum (Sweden). Sites outside Europe are also listed. The Kakadu National Park near Darwin vividly displays the long tradition of Australian rock art; southern Africa is represented by Tsodilo (Botswana), the Drakensberg-uKhahlamba (South Africa) and the Matobo Hills (Zimbabwe), while Tassili n'Ajjer (Algeria) and Tadrat Acacus (Libya) illustrate the rock art of the Sahara. In the Americas the exceptional rock-art sites of Cueva de las Manos in Patagonia and the Sierra de San Francisco in Mexico are listed.

Among the sites representative of the Andean civilizations are Machu Picchu 


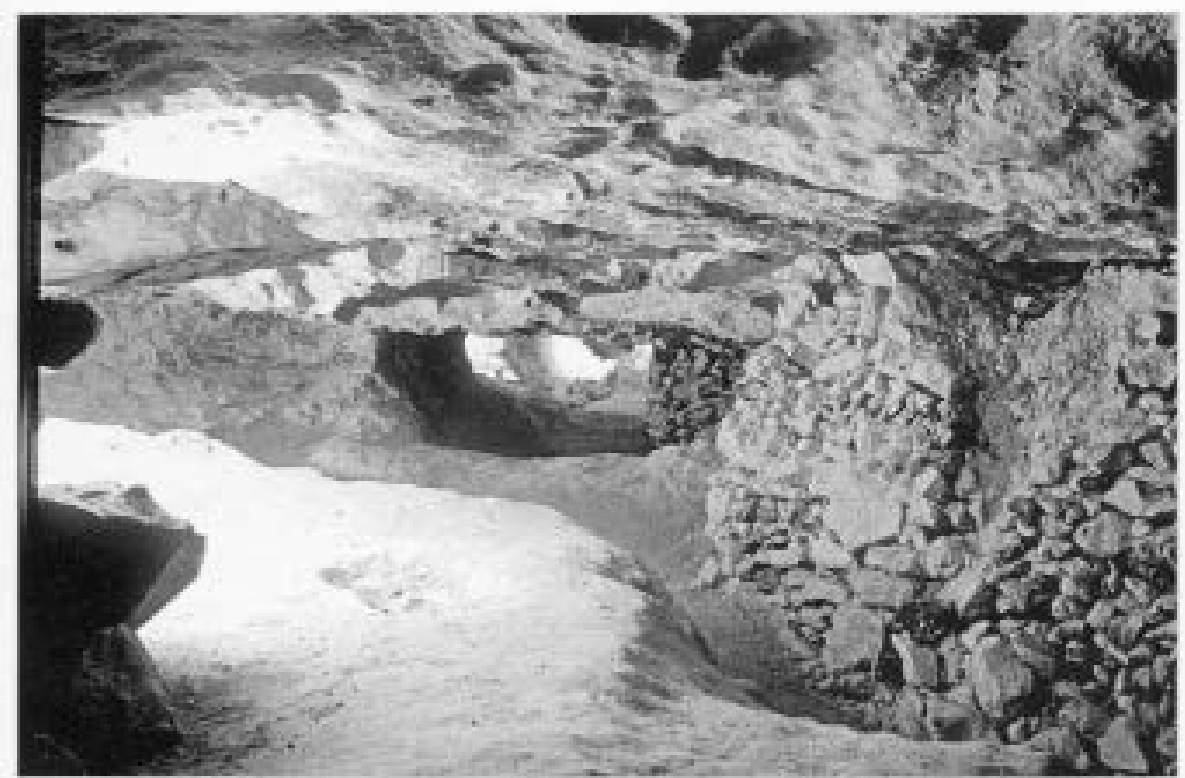

Figure 6 Neolithic flint mines at Spiennes, near Mons, Belgium.

and Tiwanaku in Peru, and in Central America and Mexico most of the famous Mayan sites are included, such as Copan (Honduras), Tikal (Guatemala), and Palenque, Chichén Itzá (Fig. 7) and Uxmal in Yucatan, as well as the great urban centres of Monte Alban and Teotihuacan (Mexico). The early site of Palenque-Casas Grandes (Mexico) provides a link with the Pueblo sites of Chaco Canyon and Mesa Verde in the southwestern USA.

Many of the most famous monuments and sites of India, such as the Taj Mahal and the stupas (Buddhist sacred monuments) of Sanchi, are on the List, as are the three great sites of the Cultural Triangle of Sri Lanka: Anuradhapura (Fig. 8), Polonnaruwa and Sigiriya). In Southeast Asia Angkor (Cambodia) is listed, although so far not the equally spectacular site of Bagan (Myanmar), because of its appalling record of management. Far out in the Pacific is Rapa Nui (Easter Island), outstanding in archaeological terms perhaps more for its fossilized landscape than for its famous statues. The only listed archaeological site in Japan is the group of stone castles of the Ryukyu kingdom on the island of Okinawa. The Qin tombs at Xi'an, with their famous terracotta army (Fig. 9), are the most important archaeological site in China, which also boasts the Great Wall and several sacred mountains with important monuments. Work is now beginning on the nomination of a group of Silk Road sites in western China, which will link with projected nominations of other sites on the Silk Road in Kazakhstan, Kyrgyzstan and other Central Asian republics. The great urban site of Merv in Turkmenistan, where staff and students from the Institute of Archaeology have been work-

ing for the past 12 years, ${ }^{7}$ is already on the List.

It will be obvious to any archaeologist that the World Heritage List does not contain a balanced and representative selection of the world's archaeological sites. This is attributable to two causes. First, the right to make nominations to the List is restricted to national governments. As a result, these nominations relate to contemporary national boundaries and do not necessarily represent the best examples of any individual culture or civilization. Decisions regarding listing are all too frequently made on political rather than cultural grounds. Secondly, no systematic attempt has ever been made to identify discrete geographical-cultural provinces and to select from the total corpus of remains those that are the most complete and best preserved and most effectively illustrate the evolution and decline of cultures and civilizations, irrespective of contemporary frontiers. Proposals were made as long ago as 1992 by ICOMOS to launch studies of this kind, but these did not prove acceptable to the diplomats and civil servants who make up most of the national delegations to the World Heritage Committee. Only recently have the geographical and cultural imbalances in the List become so blatant as to call its credibility into question, and as a result belated attempts are being made to carry out wide-ranging studies of the type proposed a decade ago. Those so far carried out by ICOMOS include studies of fossilhominid sites, rock art, and Roman theatres and amphitheatres. Also, in association with The International Committee for the Conservation of the Industrial Heritage (a non-governmental organization) there have been thematic studies of historic bridges, canals, collieries, company towns and railways. It remains to be seen whether these will in due course achieve the recognition that they merit and succeed in

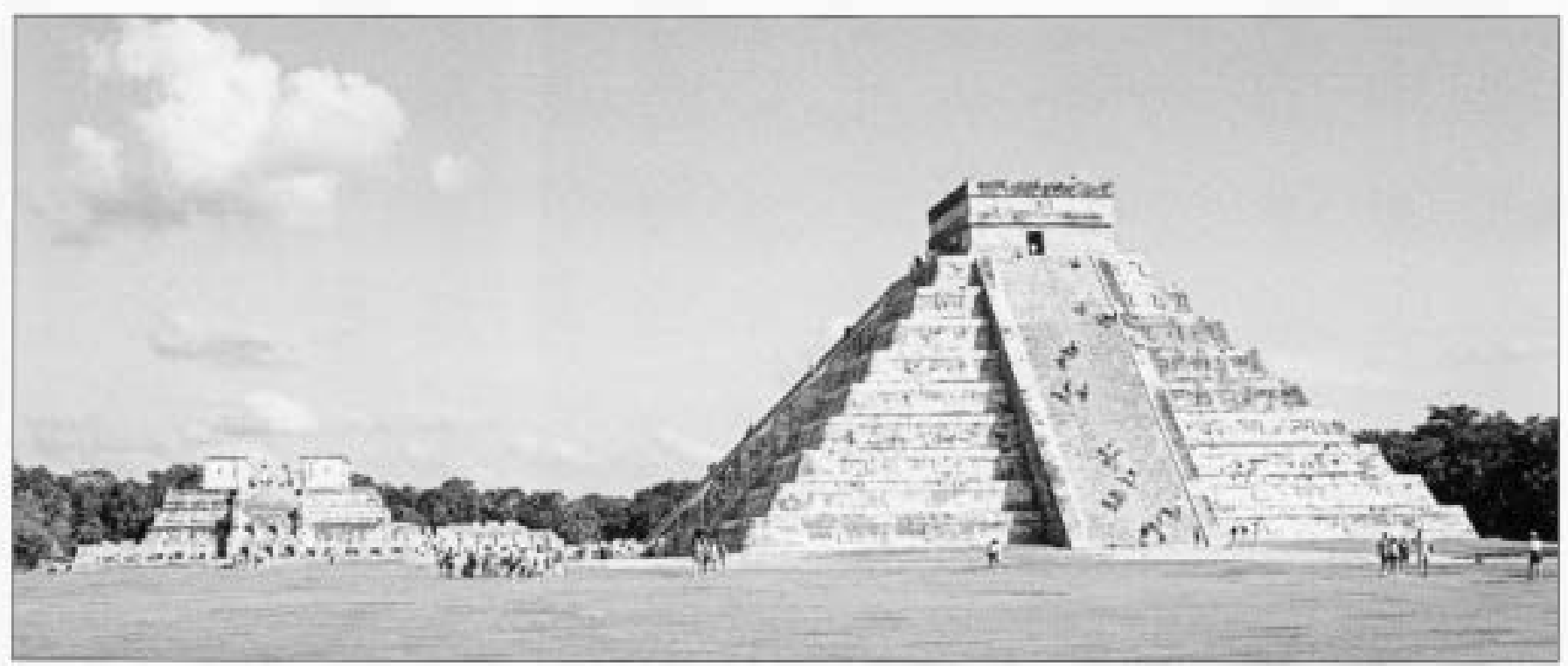

Figure 7 The pyramid of Kukulcán (El Castillo) and in the background the Templo de los Guerreros at the Mayan site of Chichén Itzá, Yucatan, Mexico. 


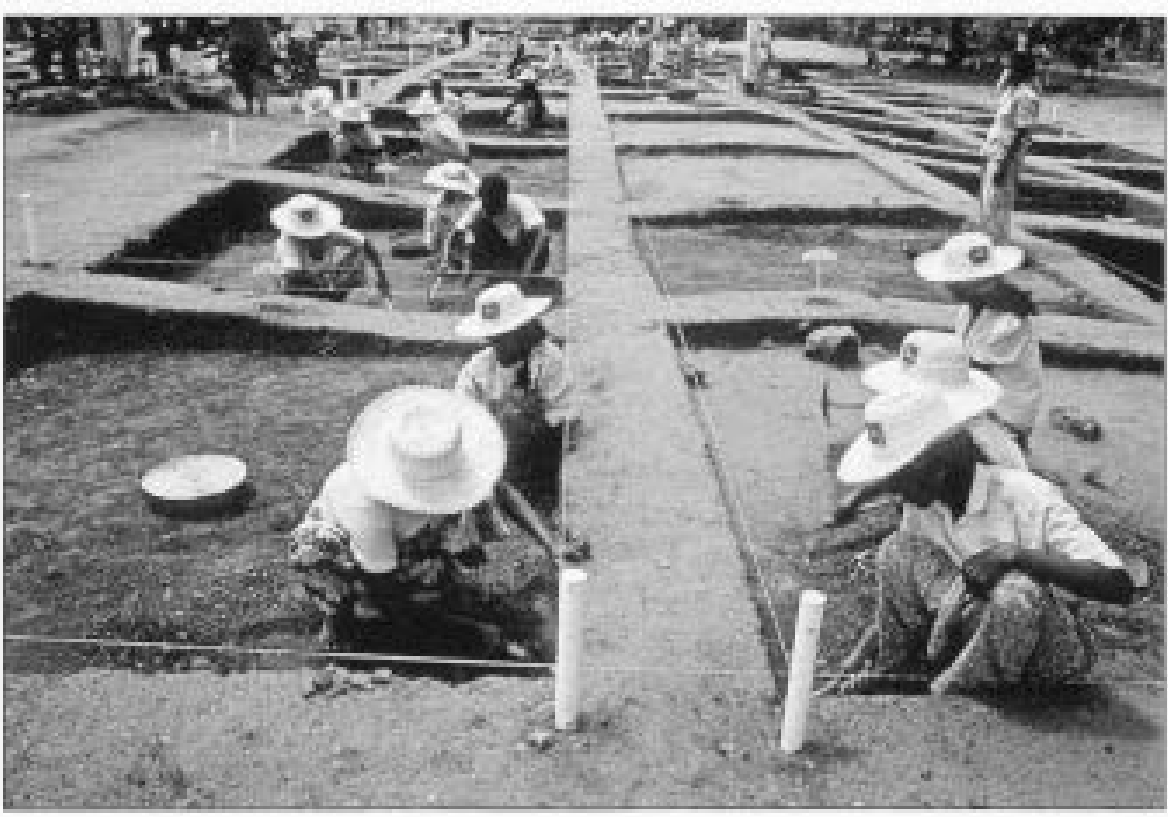

Figure 8 Excavation on progress at the site of a monasteryat Anuradhapura, Sri Lanka.

overcoming national aspirations and prejudices to make the List truly representative of millennia of human achievement.

\section{Conclusion}

As quoted from its preamble at the beginning of this article, the 1972 UNESCO World Heritage Convention is designed to identify and preserve those "parts of the heritage [that] are of outstanding interest and therefore need to be preserved as part of the world heritage of mankind as a whole". The Convention has succeeded in ensuring the sustainability of at least the most outstanding elements of the cultural heritage of humankind, but it is still far from perfect in its application at its chosen global level. It constitutes a paradigm for the protection, conservation and manage- ment of cultural heritage that should be at every level of government. But its approach to the selection of sites and monmontection needs to become World Heritage List. Within the world's archaeological community an immense fund of specialized knowledge exists. It is this community who should be called upon to identify those parts of the global archaeological heritage that are most worthy of preservation for humankind as a whole.

\section{Notes}

1. See www.international.icomos.org for details of the Venice Charter and other ICOMOS charters, including the Lausanne Charter on the Conservation of the Archaeological Heritage.

2. The Committee is composed of 21 of the States Parties to the Convention, one third of which retire each year. The presidency is held by the representative of the country in which the annual meeting of the Committee is held. The currentmembership is China (President), Argentina, Bénin,

Chile, Colombia, Egy pt, India, Japan, Kuwait, Lebanon, Lithuania, The Netherlands, New Zealand, Nigeria, Norway, Oman, Portugal, Russian Federation, St Lucia, South Africa and the United Kingdom.

3. Full information about the Convention can be obtained from the website of the UNESCO World Heritage Centre: www.whc. unesco.org/nwhc/pages/ homepage.htm

4. Operational Guidelines for the implementation of the World Heritage Convention (Paris: UNESCO, Document WHC/2/ Revised, January 1999).

5. L. Pressouyre, La Convention du Patrimoine Mondial, vingt ans après (Paris: UNESCO, 1993); English translation: The World Heritage Convention, twent y years later (Paris: UNESCO, 1996).

6. For an account of recent work at Volubilis by members of the Institute of Archaeology, see pp. 36-39 in AI 2001/2002.

7. For an account of recent work at Merv by members of the Institute of Archaeology, see pp. 40-43 in AI 2002/2003.

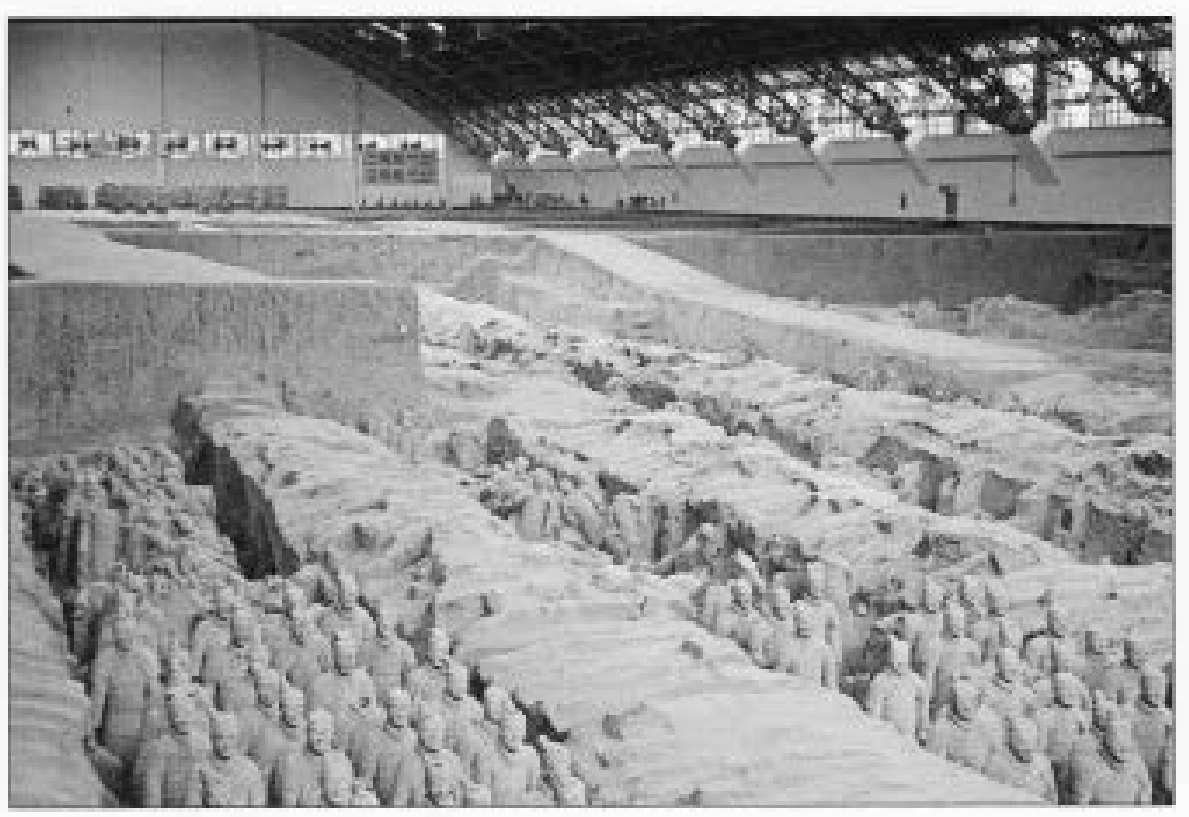

Figure 9 The Museum of the Emperor Qin Shihuang's Terracotta Army, Xi'an, China. 